\title{
Fragmentation of International Legal System Established for the Governance of the Oceans
}

\author{
Jorge Sánchez ${ }^{1}$, Paola Tafur ${ }^{2}$ \\ ${ }^{1}$ CYNERGIA Investigation Group, Department of Law, Universidad Surcolombiana, Neiva, Colombia \\ ${ }^{2}$ CYNERGIA Investigation Group, Department of Political Science, Universidad Surcolombiana, Neiva, Colombia
}

Email address:

jorgepitay@hotmail.com (J. Sánchez),m.paolatafur@gmail.com (P. Tafur)

\section{To cite this article:}

Jorge Sánchez, Paola Tafur. Fragmentation of International Legal System Established for the Governance of the Oceans. Social Sciences. Vol. 4, No. 4, 2015, pp. 86-89. doi: 10.11648/j.ss.20150404.13

\begin{abstract}
The paper presented below is intended to reveal the institutional and substantive inconsistencies within the international legal system instituted for the governance of the oceans -UNCLOS-, from a literature review of various theoretical approaches related to fragmentation of international law. So, what is contained in the document it was initially oriented to the context of the reader by presenting the theoretical guidelines necessary for the understanding of the legal system in question, and then directed towards the realization of a critical analysis of the operation of such a legal system.
\end{abstract}

Keywords: Institutional and Substantive Inconsistencies, System Instituted for the Governance of Oceans, Fragmentation of International Law

\section{Introduction}

The growing political, economic and military significance, that has characterized the sea, conflicts arising from the exercise of sovereignty over this and the consequent need for a system of international marine law to respond in a coherent and effective way. Such disputes, led to the United Nations Convention on the Law of the Sea (UNCLOS), which rises through the three conferences of the United Nations Law of the Sea, as one of the most important legal instruments of public international law [1].

Consequently, as a result of the third conference, UNCLOS arises in 1982, signed in Jamaica by one hundred nineteen (119) delegations. This instrument covers issues such as the division of the sea, influence, rights and obligations of coastal states in them, the sea area of selfdetermination by each state, and the proclamation of the "Area" as a common heritage of humanity [2].

\section{Permanent Institutions Created Under UNCLOS}

There are three (3) institutions, with clearly defined functions to which the management of the convention is entrusted [3]:

- The Committee on the Outer Limits of the Continental
Shelf (CLCS): It inspects the information issued by coastal states with respect to their limits when they exceed two hundred (200) nautical miles, and presents the respective recommendations for adapting them. (UNCLOS Annex II).

- International Seabed Authority (ISA): Established under section four (4) and five (5) of Part XI of UNCLOS. Watch scans performed by states in the seabed and manages the resources found in the area.

- International Tribunal for the Law of the Sea (ITLOS): There are two types of jurisdictions [4]:

a) Material Jurisdiction: Under which the International Tribunal for the Law of the Sea (ITLOS), may intervene in the treatment of disputes arising directly from the interpretation and application of the convention, and others in that under other international agreements recognize its jurisdiction.

b) Advisory Jurisdiction: Allows the ITLOS issue opinions that are relevant to what is addressed by the convention. As a rule ITLOS will know in plenary disputes and requests within its competence. However, it may establish chambers that, in accordance with the rules laid down in the convention, address certain matters discussed as if it were the full court who acted. E.g. Disputes Chamber Seabed. 


\section{Routes Set for the Treatment of Disputes Regulated by UNCLOS, Part XV}

The first of Part XV of the convention section brings this to the Parties in dispute, its duty to resolve them through peaceful means, aimed at maintaining the peace, international security and justice, by agreeing to the use of different processes to the courts, instituted in the second Part of the same section.

In light of the foregoing, the processes leading to binding decisions only proceed as the following assumptions are met, as determined by UNCLOS:

1. Pacific treatment instituted in the first section of Part XV does not lead to settlement of the dispute.

2. By agreement of the Parties there would not have been set a route other than a mandatory solution or a deadline, which differed within the possibility of intervention of the jurisdictional privileges set forth, in that paragraph.

If configured the above situations, the Parties, in dispute agree freely and voluntarily in choosing any of the relevant procedures under the second Part of section XV of the convention:

- International Tribunal for the Law of the Sea (UNCLOS Annex VI).

- International Court of Justice.

- Arbitral Tribunal (UNCLOS Annex VII).

- Special Arbitral Tribunal (UNCLOS Annex VIII).

Though, in the general rule on the choice of voluntary mandatory procedure, four assumptions are opposed:

a) If there is no agreement between the Parties on the means used to search for the solution to the dispute, it is understood that the procedure is set out in Annex VII of the Convention.

b) In cases before arbitration tribunals, precautionary measures may be requested before the permanent privileges, if these have not yet been made.

c) In the absence of agreement between the Parties on the process aimed at treatment of disputes relating to the prompt release of vessels and their crews, the ITLOS have compulsory jurisdiction.

d) Disputes Chamber Seabed, of ITLOS, has mandatory jurisdiction over disputes relating to activities in the "Area".

\section{Methodology}

The research was developed under a qualitative approach, using the methodological design of documentary research, as it allows addressing in detail the object of study from a comprehensive review of various documents that have studied this phenomenon.

This was done in three phases [5]:

1. Preparation. It was aimed at identifying theoretical elements that justify conducting this investigation, individualized and contextualize the phenomenon under study.

2. Description. It headed the revision, review and description of the information obtained from the thematic units, which integrate different thematic clusters.

3. Interpretation. The data obtained in the descriptive phase was analyzed to provide new theoretical elements that expand the scientific development of the phenomenon under study.

The documentary research model proposed in the document cited consists of five phases named: Preparatory, Descriptive, Interpretative Global Theoretical Construction, Extension and Publication. However, for purposes of this research the first three phases were only taken into account, because the object of study is not to identify the current state of discussion dealt about the phenomenon, but reveal the institutional and substantive inconsistencies within the International Legal System instituted for the Governance of the Oceans.

\section{Distinctive Elements of the International Legal System Established for the Governance of the Oceans}

The regulated nature of disputes, the commitments made by states and codified by the system of law in question, derived the following characteristic elements [6]:

a) Flexibility:

UNCLOS, Article two hundred eighty-seven (287) of Part $\mathrm{XV}$, allows Parties in dispute to determine freely and voluntarily the process leading to its solution. The exceptions are noted above.

The convention gives States Parties the power to appoint the arbitrators, which has set out in Annex VI and VII, integrates arbitration courts and special tribunals. However, the quality and the number of arbitrators appointed by the States Parties for each type of court are different because of the technical, legal, and scientific requirements demanded from the treatment of disputes regulated in either Annex.

As for the ICJ and ITLOS, it allows you to hear cases under their jurisdiction in plenary or through rooms, at the request of the Parties.

b) Completeness:

Article two hundred eighty-eight (288) of Part XV of UNCLOS provides that the various territorial jurisdictions are competent to hear all disputes relating to the application and interpretation of the convention.

c) Easily accessible:

It is predicated more on the ITLOS, while its competence in person, through Disputes Chamber Seabed expands over cases where the Parties in the litigation process are not just states [7]. An opposite situation occurs with the ICJ, whose jurisdiction has restricted itself to the knowledge of disputes where the Parties are exclusively states [8].

On the other hand, the Parties involved in litigation, whose knowledge is in charge of ITLOS, can receive financial assistance to cover costs related to the judicial process [9].

d) Easy Application:

As long as the regulations that apply obey to the codification of customary rules, that is to say, recognized as 
valid by the international community, even before insertion of a written instrument [10].

e) Efficiency in handling cases:

The effectiveness of the system refers to the treatment of the causes when the Parties in dispute have agreed to the choice of one of the jurisdictional privileges. Such efficiency is most evident in three aspects:

1. The active Participation of the Parties in dispute to the clear determination of the facts. Such Participation is seen in both the ICJ and ITLOS, through the two stages where the knowledge of the cause takes place, the first one written and the second one orally [11].

2. The time set for each stage. To this extent the ITLOS, has established "The proceedings before the Court Shall Be Conducted without unnecessary delay or expense" [12].

Greatly reducing the time used by the ICJ, to give treatment to known cases by this court.

3. The procedure, when the dispute is submitted to the jurisdiction of the courts of arbitration, referred to in Annex VII and VIII of the convention, will be determined by the panel, ensuring the Parties in dispute their right to defense.

\section{Results and Discussion}

The fragmentation of international law, as evidenced in the creation of standards and specialized and independent courts in the application of these regulations [13]. This has led to the formation of specialized systems of international law, as the one established for the effective governance of the oceans. If whether it originates in the social dynamics and the challenge of the contemporary right to give treatment to emerging international relations, sometimes "creates the danger of rules, principles, standard systems and mutually contradictory and incompatible practices"[14]. Posing problems of institutional and substantive type which generates inconsistencies in the operation of international law.

The International Law Commission of the United Nations states that the institutional problems "have to do with the jurisdiction and competence of various institutions applying international legal rules and hierarchical relationships between them." While the substantive problems are related to "the division of law in highly specialized "frameworks" that claim to have relative autonomy from each other and the general law." [15]

In connection with the above information, a question emerges: Is UNCLOS a system of international law specialized in consistent application?

In order to establish consistent application of the International System of the Law of the Sea, there will be determined whether there are problems of institutional and substantive types from the distinctive elements thereof.

So, as to the possible fragmentation of the legal framework created for the effective governance of the oceans, from the institutional problematic, consistency of actions shall be determined in the various competent jurisdictional privileges, under UNCLOS, for the treatment of disputes governed by the convention.
By linking the attributes of each of the courts, recognized in the convention, with the distinctive elements of the international system of law of the sea, it can be said that although the establishment of the effective governance of the oceans, in principle, is consistent institutionally, to establish a horizontal hierarchy, including compulsory procedures entailing binding decisions, as evidenced in the power of the Parties in dispute to agree to the competent jurisdiction of the case and the possibility for them to hear all matters relating to the interpretation and application of the convention, there are characteristics of ITLOS, as exceptions to the voluntary choice of the competent court jurisdiction, its broad competence in person, the possibility of offering financial assistance to the Parties to submit the case to its knowledge and the time established to resolve disputes. Although guaranteeing access to justice and timely implementation of the same, giving the ITLOS superiority over other judicial jurisdictions, leading to what the writers have called as "the choice of absolute immunity" and blur the horizontal hierarchy [16].

Furthermore, in connection with the decisions made by each of the jurisdictional privileges entailing binding decisions, this must stand that disputes were initially competence of arbitral tribunals, they ended up being resolved by the ITLOS, by agreement of the Parties in dispute [17]. In the same vein, the pronouncements of the ICJ, in relation to disputes that currently regulates UNCLOS, are derived from the powers conferred by the United Nations to this and not granted by Part XV of UNCLOS [18].

Thus, analyzing the statements grounded in the rules and the powers conferred by UNCLOS, it is summarized to study the jurisprudence of ITLOS, as shown by the judicial hegemony of the tribunal instituted for ocean governance regime.

However, when comparing the rulings of the ICJ issued by the ITLOS, in relation to disputes covered by UNCLOS, regardless of the instrument which granted them jurisdiction to hear each case, consistency is evident, while both permanent courts cited each other frequently for the substantiation of its decisions.

Nevertheless, to establish the substantive consistency of UNCLOS, it is appropriate to address both the regulatory provisions of UNCLOS as the high level of expertise in certain areas, some jurisdictional privileges with respect to others, and autonomy that can result in certain situations.

Thus, it becomes useful to indicate that the regulatory instrument, which gives positive foundation to the regime instituted for ocean governance is the result of encoding a number of customary rules [19] which, being done on a consensual basis, prevents the presentation of restraints by states against any of the items that comprise it. This, combined with the flexibility of the specialized system, provides a glimpse of the regulatory system used by the various jurisdictional privileges to give solution to disputes covered by UNCLOS.

Regarding the high level of expertise possessed by some jurisdictional privileges, there are two aspects that embody this situation:

On the one hand, arbitration tribunals established under Part 
VIII of the convention will consist of experts who know of disputes, regulated by UNCLOS, relevant to fisheries, protection and preservation of the marine environment, marine scientific research, navigation, and pollution from ships and dumping.

On the other hand, disputes arising from the activities in the "Area", to be proclaimed as World Heritage, the living Seabed Disputes, as only permanent room from ITLOS, will be competent to know them.

The above assumptions reveal a high degree of specialization by the ITLOS, through the Seabed Disputes Chamber and Special Arbitration Courts, which by giving them a relative autonomy from the other judicial jurisdictions, instituted under UNCLOS, embodies the substantive issue derived from fragmentation of international law.

\section{Conclusions}

The system instituted for the governance of the oceans, with a sample of the fragmentation of international law system has issues both institutional as well as substantive that reveal inconsistencies within it, as evidenced in the absence of the proclaimed horizontal hierarchy of the various jurisdictional privileges and the hegemony of ITLOS, without this prevents mentioning it as a system of effective implementation, while guaranteeing access to justice and the prompt settlement of disputes.

Likewise, the substantive and institutional issues, within specialized systems of law, keep a broad relationship, while representing each other's existence. E.g. The compulsory jurisdiction, that breaks the horizontal hierarchy of the Seabed Disputes Chamber, belonging to the ITLOS, is due to the specialization of it in controversies in the "Area", which gives it autonomy from other judicial jurisdictions.

Finally the effectiveness enjoyed by UNCLOS, is mainly due to the mere will of the jurisdictional privileges, since the elucidated supremacy of one of them could lead to the existence of conflicting jurisprudence and thus jeopardize the effective implementation of the instituted system for the governance of the oceans.

\section{References}

[1] RIVERO, J. (2010). El Tribunal Internacional de Derecho del Mar. Retrieved on September 24, 2014 http://www.revistafacultadderecho.edu.uy/ojs2.4.2/index.php/r $\mathrm{fd} /$ article/view/80/83.

[2] TRIBUNAL INTERNACIONAL DEL DERECHO DEL MAR. (2011). Tribunal Internacional del Derecho del Mar. Retrieved on October 18, 2014: http://www.itlos.org/fileadmin/itlos/documents/brochure/ITL OS_Brochure_spanish.pdf.

[3] ORGANIZACIÓN DE LAS NACIONES UNIDAS. (2001). Convención de las Naciones Unidas Sobre el Derecho del Mar - Convemar-. Retrieved on August 15, 2014: http://www.un.org/depts/los/convention_agreements/texts/uncl os/convemar_es.pdf.
[4] CABRERA, M. (2013). El Tribunal Internacional del Derecho del Mar. La institución judicial para el régimen de los océanos. Retrieved on October 25, 2014: http://sedici.unlp.edu.ar/bitstream/handle/10915/31598/Docu mento_completo__pdf? sequence $=4$.

[5] HOYOS, C. (2000). Un modelo para investigación documental: guía teórico-práctica sobre construcción de Estados del Arte con importantes reflexiones sobre la investigación. Medellín, Señal Editora.

[6] CABRERA, Op.Cit. p. 48-51.

[7] ORGANIZACIÓN DE LAS NACIONES UNIDAS. Op.Cit. Parte XV Sección 1 Art. 285, Parte XI sección 5, Anexo VI Art. 14.

[8] INTERNATIONAL COURT OF JUSTICE. (2014). International Court Of Justice. Retrieved on October 26, 2014:http://www.icj-cij.org/homepage/sp/files/notice.pdf.

[9] TRIBUNAL INTERNACIONAL DEL DERECHO DEL MAR. Op.Cit. p. 18.

[10] JIMÉNEZ, E., ARBUET-VIGNALI, H., and PUCEIRO, R., (2005) Derecho Internacional Público. Principios, normas y estructuras. Montevideo, Fundación de Cultura Universitaria, $1^{\circ}$ edic. 20 , pp. $190-191$.

[11] TRIBUNAL INTERNACIONAL DEL DERECHO DEL MAR. (2010) Guía del procedimiento judicial ante el Tribunal Internacional del Derecho del Mar. Retrieved on October 19, 2014:

http://www.itlos.org/fileadmin/itlos/documents/guide/Guide.S p.2009-1.pdf.

[12] INTERNATIONAL TRIBUNAL FOR THE LAW OF THE SEA. (2009). Rules of the Tribunal. Retrieved on October 26, 2014:

http://www.itlos.org/fileadmin/itlos/documents/basic_texts/Itl os_8_E_17_03_09.pdf.

[13] NACIONES UNIDAS, COMISIÓN DE DERECHO INTERNACIONAL (2006), Fragmentación del Derecho Internacional: Dificultades derivadas de la diversificación y expansión del Derecho Internacional. p.5. Retrieved on October 26, 2014: http://v880.derecho.unam.mx:8083/papime/pdf/5.pdf.

[14] Ibíd.p.5.

[15] Ibíd.p.5.

[16] CABRERA, Op.Cit. p. 9-14, 178.

[17] HORNA, Á. (2014). Apuntes acerca del Tribunal Internacional del Derecho del Mar: ¿Hamburgo v. La Haya? Retrieved on October 13, 2014:https://www.google.com.co/url? $\mathrm{sa}=\mathrm{t} \& \mathrm{rct}=\mathrm{j} \& \mathrm{q}=\& \mathrm{esrc}=\mathrm{s}$ $\&$ source $=$ web $\&$ cd $=1 \&$ cad $=$ rja\&uact $=8 \& v e d=0$ CBsQFjAA\&u $\mathrm{rl}=\mathrm{http} \% 3 \mathrm{~A} \% 2 \mathrm{~F} \% 2 \mathrm{Frevistas}$.pucp.edu.pe $\% 2 \mathrm{Findex} . \mathrm{php} \% 2 \mathrm{Fa}$ gendainternacional $\% 2$ Farticle $\% 2$ Fdownload $\% 2$ F $7342 \% 2$ F 75 60\&ei=KehbVPrvM-

y1sQT3s4Fo\&usg=AFQjCNHWv4rVkOgjEGPcxfeM9fo4DK e3KA\&bvm=bv.78677474,d.aWw.

[18] Ibíd. P. 4-5.

[19] RIVERO. Op.Cit. p.3. 